\title{
Immunotherapy in head and neck cancer
}

\section{Immunoterapia w nowotworach głowy i szyi}

\author{
Mateusz Sikora', Rafał Becht ${ }^{2}$ \\ ${ }^{1}$ Pomorski Uniwersytet Medyczny w Szczecinie, Studenckie Koło Naukowe przy Oddziale Klinicznym Onkologii, Chemioterapii i Immunoterapii Nowotworów, \\ ul. Unii Lubelskiej 1, 71-252 Szczecin \\ Pomeranian Medical University in Szczecin, Student Scientific Circle by the Clinical Department of Oncology, Chemotherapy and Cancer Immunotherapy \\ 2 Pomorski Uniwersytet Medyczny w Szczecinie, Oddział Kliniczny Onkologii, Chemioterapii i Immunoterapii Nowotworów, ul. Unii Lubelskiej 1, 71-252 Szczecin \\ Pomeranian Medical University in Szczecin, Clinical Department of Oncology, Chemotherapy and Cancer Immunotherapy \\ $\triangle$ rbecht@pum.edu.pl
}

\begin{abstract}
Immunotherapy is a method for the systemic treatment of malignant neoplasms. It is based on the abolition of the immunosuppressive effect of cancer cells and is meant to mobilize the host's immune system to actively combat with the disease. The group of cancers which are closely connected with the immune system includes: melanoma, non-small cell lung carcinoma (NSCLC), renal cancer, colon cancer, Hodgkin's lymphoma, and head and neck squamous cell carcinoma (HNSCC). Currently, cancer immunotherapy involves treatment with immune checkpoint inhibitors, therapeutic cancer vaccines, oncolytic virotherapy, and monoclonal antibodies. In the case of HNSCC, the most frequently used method is treatment with immune checkpoint inhibitors. An example of an immunological checkpoint is programmed cell
\end{abstract}

death protein-1 (PD-1), which may be activated in the process of carcinogenesis to repeal immune surveillance, favouring the development of neoplasm. The function of immune checkpoint inhibitors is based on abolition of the immunosuppressive influence of cancerous cells. Clinical trials show the positive effects of treating HNSCC with immunotherapy in certain patients. In comparison to standard systemic treatment with chemotherapy, immunotherapy rarely causes treatment-related adverse events (TRAEs). Greater survival and treatment response are factors which encourage the further development of immuno-oncology. In this article, we present a review of literature concerning the use of immunotherapy in the treatment of HNSCC.

Keywords: immunotherapy; head and neck neoplasms; PD-1 receptor; PD-L1 costimulatory protein.

\begin{abstract}
ABSTRAKT
Immunoterapia jest jedną z metod systemowego leczenia nowotworów złośliwych. Polega na zniesieniu immunosupresyjnego działania komórek nowotworowych i zmobilizowaniu układu immunologicznego gospodarza do czynnego zwalczania choroby. Do chorób rozrostowych ściśle powiązanych z układem immunologicznym zaliczamy m.in.: czerniaka, niedrobnokomórkowego raka płuca (non-small cell lung cancer - NSCLC), raka nerki, raka jelita grubego, chłoniaka Hodgkina oraz raka płaskonabłonkowego w obrębie głowy i szyi (head and neck squamous cell carcinoma - HNSCC). Aktualnie w immunoterapii nowotworów wykorzystuje się inhibitory immunologicznych punktów kontrolnych, szczepionki przeciwnowotworowe, terapię wirusami onkolitycznymi oraz leczenie przeciwciałami monoklonalnymi ukierunkowanymi na specyficzne antygeny guza. Przykładem immunologicznego punktu kontrolnego jest receptor programowanej śmierci-1 (programmed cell death protein-1 - PD-1), który odgrywa kluczową rolę w procesie karcynogenezy, polegającej na zniesieniu immunologicznego nadzoru, co sprzyja procesowi
\end{abstract}

rozrostowemu. W przypadku HNSCC obecnie najczęściej stosowaną metodą jest leczenie z użyciem inhibitorów immunologicznych punktów kontrolnych. Ich działanie opiera się na zniesieniu immunosupresyjnego działania komórek guza. Wyniki badań klinicznych z ostatnich lat wykazują korzystne efekty stosowania immunoterapii w HNSCC, z wyszczególnieniem podgrup pacjentów, u których efekt terapeutyczny takiego leczenia jest najlepszy. W porównaniu ze standardowym leczeniem systemowym, chemioterapią, przy stosowaniu metod immunoterapii rzadziej dochodzi do wystąpienia silnych działań niepożądanych związanych z leczeniem (treatment related adverse events TRAEs). Zwiększona przeżywalność i odpowiedź na leczenie, w porównaniu $\mathrm{z}$ dotychczas stosowanymi schematami, wpływa na szybszy rozwój immunoonkologii i zwiększone zainteresowanie tą metodą. W pracy przedstawiono przegląd piśmiennictwa dotyczącego zastosowania immunoterapii w nowotworach głowy i szyi.

Słowa kluczowe: immunoterapia; nowotwory głowy i szyi; receptor PD-1; kostymulujące białko PD-L1.

\section{INTRODUCTION}

Head and neck cancers develop in the oral cavity, pharynx, larynx, lips, salivary glands, nasal cavity, auditory canal, and paranasal sinuses [1]. Histopathologically, these tumours are mainly carcinomas (of which $95 \%$ are squamous cell cancers), but sarcomas and lymphomas can also occur. Head and neck squamous cell carcinomas are the sixth most frequently diagnosed malignancies [2,3]. Every year, about 630,000 new cases are diagnosed worldwide, causing 350,000 deaths annually [4]. Greater morbidity is observed in India, Sri Lanka, Bangladesh, and Pakistan [4]. In Europe and North America, head and neck 
cancers account for $5-10 \%$ of all cancers [4]. In the USA 54,000 new cases and 11,000 deaths are reported each year [4]. For many years, most common cancer in the head and neck region was laryngeal cancer. However, in recent years a trend can be observed, with increasing numbers of oral cavity and oropharynx cancers accompanied by decreased rates of laryngeal cancer. Nevertheless, laryngeal cancer is still the most commonly diagnosed cancer in this group, accounting for $3 \%$ of all malignancies in males [5]. Patients developing head and neck cancers are usually over 50 years old, except nasopharynx cancer, which is characterized by a different cytologic morphology and has two age-peaks of illness: between 20-35 years and in patients who are over 60 years old [1]. Risk factors for developing head and neck cancers include alcohol abuse, smoking, HPV (human papilloma virus), EBV (Epstein-Barr virus) infections, and chronic mechanical irritation of the mucous membrane. Two precancerous conditions (carcinoma in situ) can be distinguished: leukoplakia (firmly attached white patches on the oral cavity mucosa) and pachydermia (pathological thickening of the skin/mucosal tissue) [5]. Patients with head and neck cancers can be diagnosed with simultaneously coexisting secondary neoplasms, most frequently in the lower respiratory tract. Prognosis of head and neck cancer patients correlates with the clinical advancement of the disease. In highrisk patients, survival rate is poor - in patients with advanced disease mortality can reach up to $50 \%$ [3]. Median survival of patients in palliative treatment is 6-10 months [2]. The majority of patients are diagnosed with a locally advanced form of the disease and are qualified for surgical treatment followed by radiotherapy or radio-chemotherapy [2]. Patients who are not able to undergo surgery can be treated with chemotherapy or targeted therapy. Results of head and neck cancer treatment are regrettably unsatisfactory. According to aforementioned data and the toxicity induced by chemotherapy, new methods of systemic treatment (i.e. immunotherapy) have been sought. Head and neck squamous cell carcinoma (HNSCC) cells present specific, highly immunogenic antigens on their surface, which could be used as a target for therapy.

\section{THE INFLUENCE OF CANCER ON THE IMMUNE SYSTEM IN CARCINOGENESIS}

Carcinogenesis is a multi-stage process requiring many mutually interacting factors. Accumulation of genetic malformations leads to cell genome destabilization, causing uncontrolled gene expression and cell divisions. Not only cell's morphology but also its molecular appearance changes. It is possible that, on surface of such a cell, some antigens will be exposed and the immune system will recognize them as foreign and thus eliminate them. Immunological surveillance disorders in cancer development are a result of tumour tissues' immunosuppressive effects. Head and neck squamous cell carcinoma cells synthesize prostaglandin $\mathrm{E}_{2}\left(\mathrm{PGE}_{2}\right)$, tumor growth factor- $\beta$ (TGF- $\beta$ ), vascular endothelial growth factor (VEGF), interleukines (IL-6, and IL-8). These are cytokines which inhibit cytotoxic T lymphocyte activity, resulting in reduced tumor-infiltrating lymphocytes and favouring disease progression. Besides affecting T lymphocytes, the aforementioned cytokines appear to modify dendritic cell metabolism, further favouring carcinogenesis [6]. The abolition of immunological surveillance enables cancer cells to migrate beyond their place of origin and invade other body systems. Cancer cells, by secreting TGF- $\beta$ and IL-10, induce division of regulatory $\mathrm{T}$ lymphocytes, which then exert an immunosuppressive effect on cytotoxic T lymphocytes by increasing adenosine concentration. Despite this seemingly negative influence of regulatory $\mathrm{T}$ lymphocytes, their presence in the HNSCC microenvironment is a positive prognostic factor [2].

In the immunological aspect of cancer development, cytotoxic T lymphocyte associated antygen-4 (CTLA-4) is also important, likewise exhibiting an immunosuppressive effect in the tumor microenvironment.

An integral mechanism in cancer development is avoidance of antigen presentation. This occurs through reduction of major histocompatibility complex (MHC I) molecules to the minimum necessary to limit the functions of NK cells [2]. Moreover, cancer cells try to mimic physiological processes to inhibit excessive immune system aggression - they use the programmed cell death-1 (PD-1) pathway, activated by attachment of programmed cell death-ligand 1 (PD-L1) or PD-L2 to PD-1. The PD-1 is present on the surface of lymphocytes and its activation leads to lymphocyte depletion $[1,2]$.

\section{PD-1 receptor and PD-L1, PD-L2 ligands}

The PD-1 receptor is a transmembrane protein belonging to the CD28 family. It is found on T lymphocytes, B lymphocytes, dendritic cells, monocytes, and macrophages [7]. The only known ligands for the PD-1 receptor are molecules of the B7 family: PD-L1 and PD-L2. These ligands differ in their expression level between different tissues. The PD-L2 occurs more rarely than PD-L1; it is significantly involved in antigen presenting cell (APC) activation, during which time its expression increases [7]. The PD-L1 is expressed in the heart, pancreas, placenta, endothelium, liver, skin, and lungs [7]. Such distribution suggests involvement in limiting excessive immune system activity in extra-lymphoid regions. Notably, it has been shown that cancer cells are also able to synthetizes and release PD-L1, inhibiting T lymphocyte activation in inflammatory, autoimmune, and oncological diseases [8]. This mechanism has become the basis for investigating new drugs which would be able to block the PD-1 receptor.

\section{ANTIBODIES IN THERAPY}

Better understanding of the PD-1 receptor's biology enables the use of antibodies directed against it in the treatment of HNSCC. In HPV-positive cancers, the frequency of regulatory T lymphocytes in the tumor microenvironment is greater than in HPV-negative cancers [3]. The mechanism of action of anti-PD-1 antibodies involves preventing PD-L1 and PD-L2 from binding 
to PD-1. Thus, the immunosuppressive effects of cancer cells on the host immune system would be reduced [5].

\section{IPILIMUMAB}

Ipilimumab is a human monoclonal antibody which binds and inhibits CTLA-4 on T lymphocytes. Blocking CTLA-4 leads to enhanced lymphocyte activity and reduces immunotolerance, resulting in increased activity of cytotoxic lymphocytes and reduced or completely inhibited activity of suppressor lymphocytes [9]. Published results from a multi-cohort trial concerning ipilimumab efficacy in the treatment of advanced melanoma showed that the drug significantly improves survival [10]. Since 2016, an open, multi-cohort, phase III study has been conducted among a group of patient with recurrent HNSCC, comparing nivolumab and ipilimumab vs cetuximab + cisplatin/carboplatin + 5-fluorouracil [11].

\section{NIVOLUMAB}

Nivolumab is a monoclonal antibody, synthetized by genetic engineering techniques. It binds to and blocks PD-1, stimulating the proliferation of $\mathrm{T}$ lymphocytes with affinity for specific cancer antigens [12]. Nivolumab is prescribed for melanoma, renal cancer, and squamous cell lung cancer therapy. Ferris et al. published a study in 2016 which compared two therapies in patients with recurrent HNSCC who had experienced disease progression within 6 months after receiving platinum-based chemotherapy [13]. Patients from the study group were treated with nivolumab, while the control group was treated with methotrexate, docetaxel, or cetuximab. Treatment response evaluation criteria were overall survival (OS), progressionfree survival (PFS), objective response rate (ORR), safety, and quality of life (QoL). Patients qualified for the trial were over 18 years of age, had histopathologically confirmed HNSCC of the oral cavity, pharynx or larynx, suffered from advanced disease, and had not shown a response to previous platinumbased chemotherapy or had shown disease progression within 6 months since last dose. Patients were assessed as $0-1$ on the ECOG scale (Eastern Cooperative Oncology Group). During the qualification process, patients were confirmed to have efficient hematopoietic, liver, and kidney function. The study protocol required the presence of a measurable lesion according to RECIST v. 1.1 (Response Evaluation Ccriteria in Solid Tumors). Exclusion criteria were metastases to the central nervous system, active autoimmune disease, primary or secondary immune deficiency, or current immunosuppressive treatment. Patients with diagnosed HBV (Hepatitis B), HCV (Hepatitis C), or HIV infections were not qualified for the trial, as well as patients who had received Tlymphocyte-stimulating treatment in the past. Previous immunotherapy was also an exclusion criterion.

The study included 361 patients diagnosed with HNSCC who had previously been treated with radiotherapy $(91.4 \%$ of patients) and second or third line systemic treatment (54.5\% of patients) [13]. Patients were randomly assigned to two groups in a 2:1 ratio- treatment with nivolumab and standard therapy, respectively. Nivolumab was administrated at a dose of $3 \mathrm{mg} / \mathrm{kg}$ for 2 weeks. Standard therapy consisted of $40-60 \mathrm{mg} / \mathrm{m}^{2}$ of methotrexate, $30-40 \mathrm{mg} / \mathrm{m}^{2}$ of docetaxel, or $250 \mathrm{mg} / \mathrm{m}^{2}$ of cetuximab for one week. Distribution was 240 patients receiving nivolumab and 121 patients receiving standard therapy. Treatment response evaluation was assessed by RECIST v. 1.1. every 6 weeks, beginning after the nineth week from the beginning of treatment. Treatment was discontinued in the case of severe toxicity or disease progression. In the nivolumab group, treatment was not terminated when radiological progression was confirmed if clinical advantages were demonstrated. The PD-L1 expression on tumor cells was measured by immunohistochemical techniques, using rabbit anti-PD-L1 antibody (Dako North America). Results are presented in Table 1.

In the nivolumab treatment group, the most common side effects were fatigue, nausea, rash, loss of appetite, and pruritus. Gastroenterological complications, most of all diarrhoea, appeared less frequently than in the standard treatment group ( $6.8 \%$ vs. $14.4 \%$ of patients, respectively). Skin complications, primarily rash and pruritus, were more common in the nivolumab treatment group (15.7\% vs. $12.6 \%$ ). Endocrinopathies were also more common in this group, mainly hypothyroidism (7.6\% vs. 0.9\%). Pneumonia occurred in $2.1 \%$ of patients treated with nivolumab. In the nivolumab treatment group, 2 deaths due to toxicity were reported (one case of pneumonia and one case of hypercalcemia). In the standard treatment group, 1 treatment-associated death was reported by respiratory tract infection. Quality of life was comparable in both groups. Patients from the standard treatment group more frequently complained of pain, sensory problems, and social functioning difficulties. In the nivolumab treatment group, these parameters were stable or slightly improved.

TABLE 1. CheckMate 141 study results

\begin{tabular}{|c|c|c|c|c|}
\hline Parameters & Treatment with nivolumab & \multicolumn{3}{|c|}{ Standard therapy } \\
\hline Number of patients & 240 & \multicolumn{3}{|c|}{121} \\
\hline Deaths & $133(55.4 \%)$ & \multicolumn{3}{|c|}{$85(70.2 \%)$} \\
\hline Median overall survival & 7.5 months & $\begin{array}{l}\text { Methotrexate } \\
4.6 \text { months }\end{array}$ & $\begin{array}{l}\text { Docetaxel } \\
5.8 \text { months }\end{array}$ & $\begin{array}{l}\text { Cetuximab } \\
4.1 \text { months }\end{array}$ \\
\hline Median progression free survival & 2 months & \multicolumn{3}{|c|}{2.3 months } \\
\hline Objective response rate & $13.3 \%$ & \multicolumn{3}{|c|}{$5.8 \%$} \\
\hline Grade 3 and 4 adverse events associated with treatment & $13.1 \%$ & \multicolumn{3}{|c|}{$35.1 \%$} \\
\hline
\end{tabular}




\section{PEMBROLIZUMAB}

Pembrolizumab is an anti-PD-1 antibody. In a study published in 2016, Chow et al. investigated the clinical efficacy of pembrolizumab in HNSCC therapy [14]. The authors were assessing safety, ORR measured by RECIST v. 1.1, PFS, OS, and the association between response and PD-L1 expression. 132 patients over 18 years of age with histopathologically confirmed recurrent/ metastatic HNSCC were recruited. Patients were assessed as ECOG 0-1 with normal renal, liver, and bone marrow function. Patients who had previously received Tymphocyte-stimulating treatment were excluded, as well as those who had finished immunosuppressive treatment less than a week before, chemotherapy less than two days before, or another monoclonal antibody therapy less than a month before trail started. Coincidence of other neoplasms, psychological disorders, addictions, metastases to the central nervous system, HCV, HBC, HIV infections, or active autoimmune disease were conditions for exclusion.

Patients received $200 \mathrm{mg}$ of pembrolizumab intravenously every 3 weeks. Treatment was conducted for 24 months or until disease progression or treatment intolerance occurred. Patients with stable disease could continue receiving pembrolizumab. Objective response rate was assessed every 8 weeks. Treatment was suspended if grade 3 adverse effects appeared and was resumed when they decreased to grade 1 or 0 . If grade 3 adverse effects persisted for 12 weeks after stopping pembrolizumab injections, the patient was disqualified from the trial. Patients were immediately disqualified when grade 4 adverse effects occurred. The PD-L1 expression was examined using immunohistochemistry techniques and anti-PD-L1 antibodies (Dako North America). It was measured on both cancer cells and mononuclear inflammatory cells. Positive PD-L1 expression was defined as $\geq 1 \%$. Programmed cell death-ligand 1 expression on immune cells correlated with pembrolizumab treatment efficiency. When PD-L1 expression on immune cells was taken into consideration in analysis, pembrolizumab efficiency significantly increased. Results are showed in Table 2.

After 9 months median follow-up, ORR was 18\%, as measured by Central Imaging Vendor Review, and 20\%, as measured by the authors. A complete response was achieved in $3 \%$ of patients and a partial response in $15 \%, 20 \%$ of patients showed stable disease and $46 \%$ experienced disease progression. Within the group of HPV-positive patients, ORR was $32 \%$, while it was $14 \%$ in the HPV-negative group. A reduction in tumour size was observed in $61 \%$ patients. Median time to achieve response was 2 months. Median PFS was also 2 months. Half

TABLE 2. KEYNOTE-012 study results

\begin{tabular}{lcc}
\multicolumn{1}{c}{ Parameters } & $\begin{array}{c}\text { Negative PD-L1 } \\
\text { expression }(<\mathbf{1 \%})\end{array}$ & $\begin{array}{c}\text { Positive PD-L2 } \\
\text { expression }(\geq \mathbf{1} \%)\end{array}$ \\
\hline $\begin{array}{l}\text { Objective response } \\
\text { rate }\end{array}$ & $4 \%$ & $22 \%$ \\
\hline $\begin{array}{l}\text { Progression free } \\
\text { survival }\end{array}$ & $\mathrm{NS}, \mathrm{p}=0.195$ & $\begin{array}{c}\text { Statistically } \\
\text { significant, } \mathrm{p}=0.008\end{array}$ \\
\hline Overall survival & $\mathrm{NS}, \mathrm{p}=0.132$ & $\begin{array}{c}\text { Statistically } \\
\text { significant, } \mathrm{p}=0.008\end{array}$ \\
\hline
\end{tabular}

a year PFS was achieved in 37\% of HPV-positive patients and in $20 \%$ of HPV-negative patients. Median OS was 8 months. During the trial, $53 \%, 6 \%$, and $3 \%$ of patients experienced grade 1,2 , and $3 / 4$ adverse effects, respectively. Of grade 1 and 2 effects, authors observed fatigue (21\%), hypothyroidism (11\%), loss of appetite $(7 \%)$, nausea ( $5 \%)$, pneumonia ( $2 \%)$, face swelling $(2 \%)$, abdominal pain ( $1 \%)$, dysphagia $(1 \%)$, stomatitis $(1 \%)$, and hyperglycaemia (1\%). Of grade 3 adverse effects, the authors noted pneumonia (2\%), loss of appetite ( $2 \%)$, abdominal pain $(1 \%)$, colitis ( $1 \%)$, dysphagia ( $1 \%)$, nausea $(1 \%)$, stomatitis $(1 \%)$, face swelling ( $1 \%$ ), local oedema (1\%), infections (1\%), dehydration (1\%), type 1 diabetes mellitus (1\%), and shortness of breath (1\%). Grade 4 adverse effects included primary immunological thrombocytopenia (1\%), ketoacidosis (1\%), hyperglycaemia (1\%), laryngeal oedema ( $1 \%)$, and facial oedema $(1 \%)$.

Another study, the KEYNOTE-040 study, compared OS, PFS, and ORR in a group of 247 patients treated with pembrolizumab against the OS, PFS, and ORR of 248 patients treated with methotrexate, docetaxel, or cetuximab. Patients with recurrent/ metastatic HNSCC of the oral cavity, oropharynx, hypopharynx, and larynx were recruited. Pembrolizumab was administrated at a dose of $200 \mathrm{mg}$ every 3 weeks. Median follow-up was 7.3 months. Pembrolizumab appeared to increase OS (median OS 8.4 months vs. 7.1 months), although the difference was not statistically significant. No differences in PFS were observed between groups. Patients treated with pembrolizumab showed higher ORR (14.6\% vs. 10.1\%). Pembrolizumab showed greater efficacy in the group of patients who expressed PD-L1. In the pembrolizumab group, grade 3-5 adverse effects associated with treatment occurred at a frequency of $13.4 \%$, compared to $36.3 \%$ in the control group [15].

\section{DISCUSSION}

The increasing number of patients diagnosed with HNSCC impels the search for new therapeutic methods. For early-stage disease, surgery or radical combination treatment (radio-chemotherapy) remain the standard therapy methods. Patients not qualified for surgical treatment, with locally advanced disease, with recurrent disease after radical treatment, or with metastatic disease de novo, are still left with poor therapeutic options. Clinical experience with anti-cancer immunotherapy is based on two types of neoplasms: non-small cell lung carcinoma and melanoma. Treatment of these cancers inspired implementation of immunotherapy in another cancer types.

Viral infections with HPV and EBV play a significant role in HNSCC etiopathogenesis. Their effect is associated with increased immune system involvement in these patients. Cancer cells use the PD-1 receptor to inhibit immune function, which facilitates the progression of carcinogenesis. The abolition of immune surveillance favours tumor growth and neoplastic disease progression. Blocking PD-1 receptor signalling prevents the immunosuppressive effect of PD-L1 and PD-L2 released by cancer cells. Nivolumab and pembrolizumab are examples of drugs which block the PD-1 pathway. 
Patients with recurrent/metastatic HNSCC who demonstrate disease progression after platinum-based chemotherapy experience better outcomes when treated with nivolumab: fewer deaths, higher median OS, better ORR, and fewer adverse effects in comparison with methotrexate/docetaxel/cisplatin chemotherapy. It should be mentioned, however, that median PFS is slightly lower in the nivolumab group.

The KEYNOTE-012 study did not compare pembrolizumab efficacy with that of standard treatment. Nevertheless, when studying the literature, reports of better treatment response to pembrolizumab than cetuximab can be found [16]. In the KEYNOTE-012 trial, median OS (8.4 months) was close to the highest overall survival reported, achieved in patients with recurrent/metastatic disease who were treated with platinumbased/cetuximab/5-fluorouracyl chemotherapy [17]. Median OS was better than the median OS (7 months) reported with afatinib therapy in the group of recurrent/metastatic HNSCC patients [18]. An interesting observation is that HPV-positive patients exhibit better response to treatment than HPV-negative patients. In the presented results, pembrolizumab efficiency increases when PD-L1 expression is considerd, both on cancer and immunological cells.

Currently, new clinical trials are being conducted, investigating nivolumab and ipilimumab use in HNSCC. Patients with recurrent/metastatic HNSCC tend to have better prognosis when the tumor microenvironment is infiltrated by regulatory $\mathrm{T}$ lymphocytes, which additionally emphasizes the role of immunotherapy in head and neck region malignancies. The intricacy and involvement of the immune system in carcinogenesis necessitate conducting further studies in this field and application of their results in clinical practice. Immunotherapy in HNSCC appears to be a promising method of treatment, improving patients' survival in advanced-stage disease. Perhaps novel discoveries regarding this treatment approach will reveal new predictive factors which would contribute to HNSCC-targeted therapy. The demonstrated advantages of nivolumab and pembrolizumab therapy over standard therapeutic methods should encourage such research.

\section{REFERENCES}

1. Krzakowski M, Potemski P, Warzocha K, Wysocki P. Onkologia kliniczna. Tom 2. 3rd ed. Gdańsk: Via Medica; 2015.
2. Economopoulou P, Perisanidis C, Giotakis EI, Psyrri A. The emerging role of immunotherapy in head and neck squamous cell carcinoma (HNSCC): antitumor immunity and clinical applications. Ann Transl Med 2016;4:173-85.

3. Mandal R, Șenbabaoğlu Y, Desrichard A, Havel JJ, Dalin MG, Riaz N, et al. The head and neck cancer immune landscape and its immunotherapeutic implications. JCI Insight 2016;1:e89829.

4. Vigneswaran N, Williams MD. Epidemiologic trends in head and neck cancer and aids in diagnosis. Oral Maxillofac Surg Clin North Am 2014;26:123-41.

5. Chinai JM, Janakiram M, Chen F, Chen W, Kaplan M, Zang X. New immunotherapies targeting the PD-1 pathway. Trends Pharmacol Sci 2015;36:587-95.

6. De Costa A-MA, Young MRI. Immunotherapy for head and neck cancer: advances and deficiencies. Anti-Cancer Drugs 2011;22:674-81.

7. Grzywnowicz M, Giannopoulos K. Znaczenie receptora programowanej śmierci 1 oraz jego ligandów w układzie immunologicznym oraz nowotworach. Acta Haematologica Polonica 2012;43:132-45.

8. Ferris RL. Immunology and Immunotherapy of Head and Neck Cancer. J Clin Oncol 2015;33:3293-304.

9. Weber J. Overcoming immunologic tolerance to melanoma: targeting CTLA - 4 with ipilimumab (MDX-010). Oncologist 2008;13(Suppl 4):16-25.

10. Hodi FS, O'Day SJ, McDermott DF, Weber RW, Sosman JA, Haanen JB, et al. Improved survival with ipilimumab in patients with metastatic melanoma. N Eng J Med 2010;363:711-23.

11. Argiris A, Gillison M, Ferris RL, Harrington K, Sanchez TK, Baudelet C, et al. A randomized, open-label, phase 3 study of nivolumab in combination with ipilimumab vs extreme regimen (cetuximab + cisplatin/carboplatin + fluorouracil) as first-line therapy in patients with recurrent or metastatic squamous cel carcinoma of the head and neck - CheckMate 651. Ann Oncol 2016;27(Suppl 6):328-50.

12. Guo L, Zhang H, Chen B. Nivolumab as Programmed Death-1 (PD-1) Inhibitor for Targeted Immunotherapy in Tumor. J Cancer 2017;8:410-6.

13. Ferris RL, Blumenschein G Jr, Fayette J, Guigay J, Colevas AD, Licitra L, et al. Nivolumab for Recurrent Squamous-Cell Carcinoma of the Head and Neck. N Engl J Med 2016;375:1856-67.

14. Chow LQM, Haddad R, Gupta S, Mahipal A, Mehra R, Tahara M, et al. Antitumor Activity of Pembrolizumab in Biomarker-Unselected Patients With Recurrent and/or Metastatic Head and Neck Squamous Cell Carcinoma: Results From the Phase Ib KEYNOTE-012 Expansion Cohort. J Clin Oncol 2016;34:3838-45.

15. Cohen EE, Harrington KJ, Le Tourneau C, Dinis J, Licitra L, Ahn MJ, et al. Abstract LBA45_PR „Pembrolizumab (pembro) vs standard of care (SOC) for recurrent or metastatic head and neck squamous cell carcinoma (R/M HNSCC): Phase 3 KEYNOTE-040 trial". Zaprezentowano przez Cohen EE. ESMO 2017 Congress, Lugano-Madryt.

16. Vermorken JB, Trigo J, Hitt R, Koralewski P, Diaz-Rubio E, Rolland F, et al. Open-label, uncontrolled, multicenter phase II study to evaluate the efficacy and toxicity of cetuximab as a single agent in patients with recurrent and/or metastatic squamous cell carcinoma of the head and neck who failed to respond to platinum-based therapy. J Clin Oncol 2007;25:2171-7.

17. Vermorken JB, Mesia R, Rivera F, Remenar E, Kawecki A, Rottey S, et al. Platinum-based chemotherapy plus cetuximab in head and neck cancer. N Engl J Med 2008;359:1116-27.

18. Machiels JP, Haddad RI, Fayette J, Licitra LF, Tahara M, Vermorken JB, et al. Afatinib versus methotrexate as second-line treatment in patients with recurrent or metastatic squamous-cell carcinoma of the head and neck progressing on or after platinum-based therapy (LUX-Head \& Neck 1): An open-label, randomised phase 3 trial. Lancet Oncol 2015;16: 583-94. 